\title{
Effects of long-term mowing on the fractions and chemical composition of soil organic matter in a semiarid grassland
}

\author{
Jiangye $\mathrm{Li}^{1}$, Qichun Zhang ${ }^{1}$, Yong $\mathrm{Li}^{1}$, Yimeng $\mathrm{Liu}^{2}$, Jianming $\mathrm{Xu}^{1}$, and Hongjie $\mathrm{Di}^{1}$ \\ ${ }^{1}$ Zhejiang Provincial Key Laboratory of Agricultural Resources and Environment, Key Laboratory of Environment \\ Remediation and Ecological Health, Ministry of Education, Zhejiang University, Hangzhou 310058, China \\ ${ }^{2}$ School of Economics and Resource Management, Beijing Normal University, Beijing 100875, China \\ Correspondence to: Qichun Zhang (qczhang@zju.edu.cn)
}

Received: 26 October 2016 - Discussion started: 28 November 2016

Revised: 13 April 2017 - Accepted: 21 April 2017 - Published: 31 May 2017

\begin{abstract}
The grassland ecosystem is a significantly important terrestrial carbon pool. Intensive mowing is common to meet the need of increased livestock. However, little information on the quality and quantity of soil organic matter (SOM) under different mowing managements has been documented. In this work, in order to evaluate the impacts of different mowing managements on the quality and quantity of SOM, the fractions and chemical composition of SOM under different mowing managements were determined using traditional fractionation methods and spectroscopy technologies, including advanced nuclear magnetic resonance (NMR) (e.g. cross-polarization magic angle spinning ${ }^{13} \mathrm{C}$-NMR, CPMAS ${ }^{13} \mathrm{C}-\mathrm{NMR}$ ) and Fourier-transform infrared (FTIR) based on a 13-year field mowing trial with four treatments: unmown (M0), mowing once every second year (M1/2), mowing once a year (M1) and mowing twice a year (M2). The results showed that compared with M0, M1/2 and M1 significantly enhanced the SOM accumulation and increased the stability of SOM by enhancing humification, while M2 limited SOM accumulation and microbial biomass. Substituted alkyl carbon (C) was the major organic $\mathrm{C}$ type in the grassland ecosystem, and it made up over $40 \%$ of the total C. M1/2 and M1 significantly increased stable $\mathrm{C}$ functional groups (alkyl $\mathrm{C}$ and aromatic $\mathrm{C}$ ) by degrading labile $\mathrm{C}$ functional groups $(O$-alkyl and carbonyl $\mathrm{C}$ ) and forming recalcitrant humus, while M2 had opposite effects. The consistent increase in the values of NMR indices reflecting the degradation degree, hydrophobicity and aromaticity of SOM in M1 reflected the fact that M1 had the largest contribution to increasing the stability of SOM, while these values in M2 were similar to those in M0. Significant correlations between different SOM frac-
\end{abstract}

tions and nitrogen $(\mathrm{N})$ mineralization, and between the contents of different $\mathrm{C}$ functional groups and net soil organic nitrogen mineralization or microbial biomass $\mathrm{C}$, indicated that the shifts in SOM fractions and chemical composition were closely related to soil microbial biomass and activity. Therefore, in view of the quality and quantity of SOM and the sustainable development of grassland ecosystems, M1 was the optimal mowing management, while M2 should be avoided in the semiarid grassland.

\section{Introduction}

Soil organic matter (SOM) plays a central role in the global biogeochemical cycles of most major nutrients. The soil $\mathrm{C}$ pool is the largest $\mathrm{C}$ storage in the terrestrial ecosystem and the organic $\mathrm{C}$ pool consists of more than $90 \%$ of the total soil C pool. Grasslands account for $40.5 \%$ of the terrestrial area globally, and it is estimated that $34 \%$ of the global terrestrial organic $\mathrm{C}$ was stored in the grasslands (White et al., 2000). In China, grasslands also cover more than $40 \%$ of the terrestrial surface and the Inner Mongolia grassland, which is one of the most important animal husbandry bases, representing more than a quarter of the total grassland area (National Environment Protection Bureau of China, 2006). Therefore, soil $\mathrm{C}$ and nitrogen $(\mathrm{N})$ cycling in Inner Mongolia grassland has been a hot topic (Shan et al., 2011; Wang et al., 2014, 2016). Mowing once a year is one of the common practices in grassland ecosystems, and it is reported that mowing once a year increases the stocks of soil $\mathrm{C}$ and $\mathrm{N}$ by facilitating plant species richness, plant productivity, root biomass and 
root exudates (Socher et al., 2012; Cong et al., 2014). However, in order to prepare enough winter feed for the increased livestock, high-frequency mowing is needed, which might result in the reduction of plant species diversity and block soil $\mathrm{C}$ and $\mathrm{N}$ turnover, as few microbes are able to bear such a degree of disturbance.

Increased plant diversity and enhanced fresh SOC input by mowing once a year can lead to the degradation of recalcitrant organic compounds by the priming effect (Fontaine et al., 2011). In addition, different plant species release diverse organic compounds, and these would have an impact on soil microbial communities (Dijkstra et al., 2005). It was documented that mowing could increase the activity of extracellular enzymes to decompose polymeric $\mathrm{C}$ (aromatic polymer from lignin derived from litter or root residue) into monomers (Steinauer et al., 2015), including simple but resistant C like alkyl C, a decomposition product which is stable in soil. The stability of the soil C pool is closely related to the sustainability of soil functions. However, it has been unclear how stable the SOM is under the different mowing managements. Therefore, to better assess the ecological significance of long-term mowing managements, it is necessary to study the impacts of different mowing managements on the quantity and quality of SOM.

Soil organic matter composition is often used to evaluate the stability of soil $\mathrm{C}$ pools. The fractions of SOM are traditionally classified based on the assumption of organomineral interactions and spatial arrangements of soil particle size by physical methods (Cao et al., 2011) and relying on their solubility in acid or base extractants by chemical methods (Olk and Gregorich, 2006). Generally, labile SOC fractions include water-soluble organic $\mathrm{C}$ (WSOC), microbial biomass $\mathrm{C}$ (MBC) and readily oxidized $\mathrm{C}$ (ROC), which are considered to be early and sensitive indicators of soil quality because they could rapidly respond to soil management practice (Chen et al., 2017), while humus is recalcitrant SOM. These fractions are extracted by different extractants. Spectroscopy is a powerful tool for identifying the chemical structures of SOM as soil samples are measured directly rather than determined after a series of extractions which might alter the nature of SOM. Fourier-transform infrared spectroscopy (FTIR) and nuclear magnetic resonance (NMR) are widely used to study the chemical composition of organic matter (Olk, 2006; Mao et al., 2008; Zhou et al., 2014). Advanced solid-state NMR, i.e. cross-polarization magic angle spinning ${ }^{13} \mathrm{C}$-NMR (CPMAS ${ }^{13} \mathrm{C}$-NMR) applied in characterizing chemical structures of SOM, is also an important approach to reveal the essential changes in SOM formation and degradation in paddy fields and forest ecosystems (Zhou et al., 2014; Panettieri et al., 2014; Zhang et al., 2015) and in litter and wood decomposition processes in these ecosystems (Sanaullah et al., 2012; Bonanomi et al., 2013; Hu et al., 2017). This approach can provide the information of SOM structure noninvasively without using solvents. Generally, alkyl C (45-0 ppm), $N$-akyl/methoxyl C
(60-45 ppm), $O$-alkyl C (90-60 ppm), di- $O$-alkyl C (11090 ppm), aryl C (140-110 ppm), phenolic C (165-140 ppm) and carboxyl and carbonyl C (210-165 ppm) are identified in detail, from the spectra of ${ }^{13} \mathrm{C}$-NMR of soil samples (Baumann et al., 2009, 2013; Zhao et al., 2012). This functional $\mathrm{C}$ can also be generally grouped into four groups: carbonyl C (210-165 ppm), aromatics C (165-110 ppm), substituted alkyl C (110-45 ppm), and alkyl C (45-0 ppm) (Plaza et al., 2013; Zhao et al., 2012; Boeni et al., 2014). In addition, alkyl, $N$-akyl/methoxyl, aryl and phenolic $\mathrm{C}$ are often derived from lignin, while $O$-alkyl and di- $O$-alkyl $\mathrm{C}$ are generally included in polysaccharide (carbohydrates) (Preston et al., 1998; Bonanomi et al., 2013). By analysing the functional $\mathrm{C}$ composition, the nature of SOM can be better understood and the quality and quantity of SOM can be more exactly evaluated. However, the cost of solid-state ${ }^{13} \mathrm{C}$-NMR is high, especially for complex soil samples, because of the length of time it takes to identify the chemical structure.

To better understand and evaluate the quality of SOM, elemental analysis (EA) and FTIR are often combined to help get more accurate information (Mao et al., 2008; Zhou et al., 2014). In grassland ecosystems, these tools are also used to study SOM stocks and quality (Baumann et al., 2016; Knicker et al., 2012). However, there are no reports of the effects of mowing and mowing frequency on the chemical structure of the whole SOM, which reflects the nature of SOM. In this study, we combined advanced solid-state NMR with traditional methods to investigate the quality and quantity of the grassland soil organic $\mathrm{C}$ under different mowing managements. The objective of this study was to investigate the impacts of long-term mowing practices on the chemical composition of SOM and evaluate the stability of the grassland soil carbon pools under different mowing frequencies.

\section{Materials and methods}

\subsection{Site description and experimental design}

The study site was located in the Xilingol region of Inner Mongolia $\left(43^{\circ} 269^{\prime}-44^{\circ} 089^{\prime} \mathrm{N}\right.$ and $\left.116^{\circ} 049^{\prime}-117^{\circ} 059^{\prime} \mathrm{E}\right)$ in northern China. It has a temperate semiarid climate, with an annual mean temperature of $0.5^{\circ} \mathrm{C}$ and annual average precipitation of $350 \mathrm{~mm}$, most of which falls during the summer. The annual potential evapotranspiration ranged from 1600 to $1800 \mathrm{~mm}$. The soil was Calcic-orthic Aridisol according to the US soil taxonomy (or sandy-loam dark chestnut soil in the Chinese classification system) (Baoyin et al., 2014) and, in the profile, there was a humus layer of $20-30 \mathrm{~cm}$ and a calcic layer at ca. $50 \mathrm{~cm}$ depth (Jiang, 1988). The characteristic vegetation of this region was Leymus chinensis ( $L$. chinensis), accounting for $55 \pm 15 \%$ (mean \pm standard deviation) of total herbage yield. Other species in order of decreasing proportion of total herbage yield are tall bunchgrasses (mostly Stipa grandis and Agropyron michnoi), short 
bunchgrasses (Cleistogenes squarrosa and Koeleria cristata (L.) Schrad) and sedge (Carex korshingski Kom.), forbs and legumes (Baoyin et al., 2014). The growing season usually started in May and ended in September.

The long-term mowing experiment has been carried out since 2001 in a permanent enclosure by the Inner Mongolia Grassland Ecosystem Research Station of the Chinese Academy of Sciences. The enclosure for the mowing experiment was divided into 12 plots $(24 \mathrm{~m} \times 20 \mathrm{~m}$ for each plot). There were four treatments, each with three replicates. The four treatments were unmown (M0), mowing once every two years (M1/2) in August, mowing once a year (M1) in August when aboveground biomass of L. chinensis reached the peak, and mowing twice every year (M2) in June when the palatability of L. chinensis was best for the livestock and in September when L. chinensis was withered.

\subsection{Soil sample collection}

Soil samples were collected from 0 to $10 \mathrm{~cm}$ depth using a soil auger $(7 \mathrm{~cm}$ in diameter and $10 \mathrm{~cm}$ in depth) in October 2013 at the end of the growing season and all plots experienced the grass cutting in this year. Five soil cores were collected from each plot at random locations and they were combined and mixed thoroughly to form a composite sample. Visible roots and litter residues and large soil fauna in the soil samples were removed. The soil samples of around $1 \mathrm{~kg}$ were put into ziplock bags and transported to the lab on ice quickly. In the lab, the soil samples were passed through a $2 \mathrm{~mm}$ sieve and subsampled into two parts. One part was air-dried for basic physical and chemical properties analysis; the other fresh part was used to analyse the fractions and chemical composition of SOM as soon as possible and, if this part could not be analysed in a short time, they were stored at $-20^{\circ} \mathrm{C}$ to avoid the impacts of storage temperature on the indicators determined, especially the microbial indicators.

\subsection{Measurements of bulk soil basic properties}

Soil $\mathrm{pH}$ was measured using a water-to-soil ratio of $2.5: 1$. Soil moisture content was determined by oven drying for $16 \mathrm{~h}$ to a constant mass at $105^{\circ} \mathrm{C}$. The content of soil organic $\mathrm{C}$ (SOC) and total nitrogen (TN), alkali-hydrolysable N (AN), Olsen phosphorus (Olsen $\mathrm{P}$ ) and net $\mathrm{N}$ mineralization was determined, referring to Kalembasa and Jenkinson (1973), Bremner (1965), Bao (2000) and Lin (2010), respectively.

\subsection{Soil organic matter fractionation}

Soil microbial biomass carbon (MBC) was extracted using the chloroform fumigation extraction (Vance et al., 1987; Wu et al., 1990) and determined using a TOC analyser (Elementar Liqui TOC, Elementar Co., Hanau, Germany). Water soluble organic carbon (WSOC) was determined using a modified method (Li et al., 2013). Briefly, WSOC was extracted from $5.0 \mathrm{~g}$ of fresh soil using a soil-to-water ratio of $1: 10$ at $25^{\circ} \mathrm{C}$, and shaken for $30 \mathrm{~min}$ at a speed of $250 \mathrm{rpm}$. The samples were subsequently centrifuged $(1146 \times \mathrm{g}, 20 \mathrm{~min})$, and then the supernatant was filtered using a $0.45 \mu \mathrm{m}$ membrane filter. The filtrate was measured by the same TOC analyser mentioned above. Soil readily oxidizable carbon (ROC) was determined and calculated following the detailed procedure described by Li et al. (2013). The mobile humic acid (MHA) and calcium humic acid (CaHA) were extracted following the procedure by Mao et al. (2008). Thirty grams of air-dry soil was used to extract the two humic fractions and the extracted humic fractions were freeze-dried using a freeze-drying machine (FD-1C-50, Beijing, China), and then weighted, respectively.

\subsection{Analysis of the chemical composition of soil organic matter (SOM)}

To remove paramagnetic materials $\left(\mathrm{Fe}^{3+}, \mathrm{Mn}^{2+}\right)$ and increase the signal-to-noise ratio, the soil samples were pretreated with $\mathrm{HF}(10 \%, v / v)$ using the procedure detailed in Li et al. (2010), and finally, the SOM samples were freezedried. It is reported that the chemical composition of SOM was not altered as the $\mathrm{C} / \mathrm{N}$ was similar before and after the HF processing (Mao et al., 2008; Zhou et al., 2014), as was the case in this study (Table S2 in the Supplement), and the $\mathrm{C}$ and $\mathrm{N}$ content in $10 \% \mathrm{HF}$-treated SOM samples and bulk soil samples was measured using a CHNS Elemental Analyzer (Carlo Erba model EA1108, Italy Vario).

\subsubsection{Elemental analysis}

The elemental composition of $10 \%$ HF-treated SOM samples was determined using the same CHNS Elemental Analyzer mentioned above. The content of $\mathrm{O}$ was estimated as the ash-free mass less $\mathrm{C}, \mathrm{H}$, and $\mathrm{N}$. Ash content was determined by combustion overnight in a muffle furnace at $500^{\circ} \mathrm{C}$ (Ussiri and Johnson, 2003).

\subsubsection{FTIR analysis}

The FTIR analysis of the SOM samples was conducted on an Avatar 370 FTIR spectrometer (Thermo Nicolet, USA). Each sample was prepared by grinding a $2 \mathrm{mg}$ freezingdrying SOM sample with $200 \mathrm{mg}$ oven-dried $\mathrm{KBr}$ in a vibrating puck mill, and then mixtures of about $150 \mathrm{mg}$ were compressed into a translucent pellet using a hydraulic compressor. The pellet was immediately placed on the sample holder, and all spectra ranging from 4000 to $400 \mathrm{~cm}^{-1}$ were recorded under the conditions of $4 \mathrm{~cm}^{-1}$ wave number resolution, 25 scans, and pure $\mathrm{KBr}$ spectra as background (Zhou et al., 2014). Absorption peaks or bands were assigned to organic functional groups following Zhou et al. (2014). Only peaks or bands in the functional group region from 4000 to $1000 \mathrm{~cm}^{-1}$ of FTIR spectra were assigned because peaks in the fingerprint region below $1000 \mathrm{~cm}^{-1}$ were difficult to as- 
Table 1. Calculation formulas of different ${ }^{13} \mathrm{C}-\mathrm{NMR}$ indices.

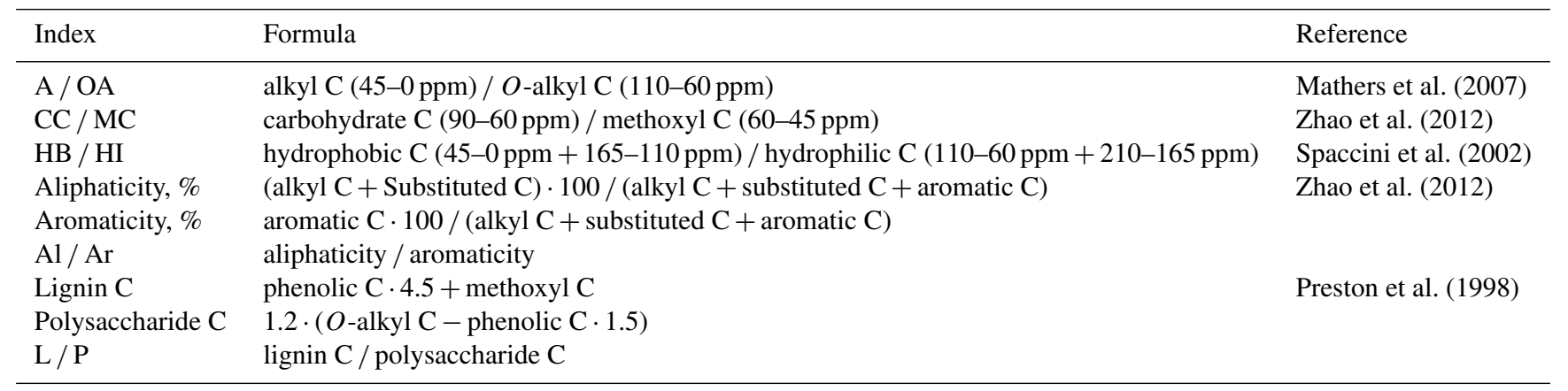

sign and were very complex, usually overlapping with signals of inorganic soil minerals.

\subsubsection{Solid-state CPMAS ${ }^{13} \mathrm{C}$-NMR analysis}

A solid-state ${ }^{13} \mathrm{C}-\mathrm{NMR}$ experiment was performed on a Bruker Avance II 300 (Bruker Instrumental Inc) equipped with a $7 \mathrm{~mm}$ CPMAS (cross-polarization magic-anglespinning) detector. NMR spectra were acquired under the conditions of a spectrometer frequency of $75 \mathrm{MHz}$, a MAS spinning frequency of $5000 \mathrm{~Hz}$, a recycle time of $2.5 \mathrm{~s}$ and a contact time of $2 \mathrm{~ms}$. The external standard used for chemical shift determination was hexam-ethylbenzene (methyl at $17.33 \mathrm{ppm}$ ). The quantified contribution of each type of $\mathrm{C}$ to the total signal intensity and promotion in CPMAS ${ }^{13} \mathrm{C}$ NMR spectrum was automatically integrated after the separation of hexam-ethylbenzene to calculate the area of the peaks which appeared in the corresponding chemical region using MestreNova software 8.1.0 (Mestrelab, Research Inc). The ${ }^{13} \mathrm{C}-\mathrm{NMR}$ spectrum was assigned into seven regions as the previous studies (Baumann et al., 2009, 2013; Zhao et al., 2012) and they were grouped into four main chemical environments according to the ${ }^{13} \mathrm{C}$ nucleus: carbonyl $\mathrm{C}(210-$ $165 \mathrm{ppm})$, aromatics C (165-110 ppm), substituted alkyl C (110-45 ppm), alkyl C (45-0 ppm) (Plaza et al., 2013; Zhao et al., 2012; Boeni et al., 2014). The seven assignments of ${ }^{13} \mathrm{C}$-NMR spectrum and potential sources of functional groups in each assignment were showed in Table S1. To better evaluate the quality of $\mathrm{C}$ pools, some indices were calculated following the formula in Table 1.

\subsection{Data analysis}

Data were statistically analysed using SPSS 21.0 by one-way analysis of variance (ANOVA), and means were separated by Duncan's multiple range test at $5 \%$ level. The figures were created using Origin 8.1 and the data were the mean values $(n=3)$. Linear regression analysis was conducted after the Pearson product-moment correlation analysis by a two-tailed test in SPSS 21.0 using the data in all mowing treatments $(n=9)$ except for the unmown (M0).

\section{Results}

\subsection{Basic properties of bulk soil and net $\mathbf{N}$ mineralization}

Soil $\mathrm{pH}$ was around 7.3 and was not affected by long-term mowing (Table 2). However, long-term mowing had a significant impact on soil nutrient concentrations. Compared with M0 (unmown), mowing once every second year (M1/2) and mowing once a year (M1) significantly increased SOC content $(P<0.05)$ while the SOC content in M2 was similar to that in M0 $(P>0.05)$. The TN content in M1 was the highest and significantly higher than that in treatment M2. The total $\mathrm{N}$ content in $\mathrm{M} 2$ was also significantly lower than those in the other two treatments (M1/2 and M0). Soil Olsen P contents in all the treatments were very low, around $1.2 \mathrm{mg} \mathrm{kg}^{-1}$, and no significant difference was observed between the treatments $(P>0.05)$. The AN content in the soil in M2 was significantly lower than those in the other treatments $(P<0.05)$, while there was no significant difference between the other treatments $(P>0.05)$. Net $\mathrm{N}$ mineralization in $\mathrm{M} 1$ was significantly greater than that in the other treatments, and it was significantly lower in M2 than that in other treatments $(P<0.05)$.

\subsection{Soil organic matter fractions}

Long-term mowing had major impacts on labile $\mathrm{C}$ and recalcitrant SOM (Table 3). Compared with M0, M1/2 significantly increased soil MBC content, while M2 significantly decreased soil MBC content $(P<0.05)$. WSOC and ROC contents in all mowing treatments were significantly $50 \%$ lower than those in M0 $(P<0.05)$. Among different mowing treatments, no difference was observed in soil WSOC content $(P<0.05)$, while the soil ROC content in M2 treatment was significantly lower than that in M1 $(P<0.05)$. The total content of both humic fractions (MHA and CaHA) accounted for a major proportion of SOM, especially in M1, where it reached $73.0 \%$ (Table 3 ), and this was significantly higher than that $(53.1 \%)$ in M2 $(P<0.05)$. The CaHA content was about 2-4 times that of MHA across all treatments. 
Table 2. Basic description of soil properties under different mowing treatments.

\begin{tabular}{|c|c|c|c|c|c|c|}
\hline \multirow[t]{2}{*}{ Treatment } & $\mathrm{pH}$ & SOC & $\mathrm{TN}$ & Olsen P & $\mathrm{AN}$ & \multirow{2}{*}{$\begin{array}{r}\text { Net } \mathrm{N} \text { mineralization } \\
\mathrm{mg} \mathrm{N} \mathrm{g}^{-1}\end{array}$} \\
\hline & $\mathrm{H}_{2} \mathrm{O}$ & \multicolumn{2}{|c|}{$\mathrm{g} \mathrm{kg}^{-1}$} & \multicolumn{2}{|c|}{$\mathrm{mg} \mathrm{kg}^{-1}$} & \\
\hline M0 & $7.3 \pm 0.1 \mathrm{a}$ & $17.9 \pm 0.6 b$ & $1.5 \pm 0.0 \mathrm{ab}$ & $1.0 \pm 0.15 \mathrm{a}$ & $75 \pm 0.59 \mathrm{a}$ & $194 \pm 3.76 b$ \\
\hline $\mathrm{M} 1 / 2$ & $7.3 \pm 0.0 \mathrm{a}$ & $20.2 \pm 1.6 \mathrm{a}$ & $1.5 \pm 0.4 \mathrm{ab}$ & $1.3 \pm 0.06 \mathrm{a}$ & $86 \pm 1.42 \mathrm{a}$ & $176 \pm 7.51 b$ \\
\hline M1 & $7.3 \pm 0.1 \mathrm{a}$ & $21.7 \pm 0.3 \mathrm{a}$ & $1.7 \pm 0.0 \mathrm{a}$ & $1.2 \pm 0.03 \mathrm{a}$ & $86 \pm 0.00 \mathrm{a}$ & $225 \pm 2.51 \mathrm{a}$ \\
\hline M2 & $7.2 \pm 0.0 \mathrm{a}$ & $17.8 \pm 0.8 b$ & $1.3 \pm 0.0 \mathrm{~b}$ & $1.2 \pm 0.03 \mathrm{a}$ & $57 \pm 0.00 \mathrm{~b}$ & $127 \pm 7.50 \mathrm{c}$ \\
\hline
\end{tabular}

M0, unmown; M1/2, mowing once every second year; M1, mowing once a year; M2, mowing twice a year. The value was the mean \pm S.E., $n=3$. SOC, soil organic carbon; TN, total nitrogen; Olsen P, Olsen phosphorus; AN, alkali-hydrolysable nitrogen; net N mineralization, net nitrogen mineralization. Different lowercase letters in the same column indicated that the difference between treatments reaches a $5 \%$ significance level.

Table 3. Effect of different mowing managements on bulk SOM fractions.

\begin{tabular}{|c|c|c|c|c|c|c|}
\hline \multirow[t]{2}{*}{ Treatment } & MBC & WSOC & ROC & MHA & $\mathrm{CaHA}$ & \multirow{2}{*}{$\begin{array}{r}\mathrm{HA} / \mathrm{SOM} \\
\%\end{array}$} \\
\hline & \multicolumn{2}{|c|}{$\mathrm{mg} \mathrm{kg}^{-1}$} & \multicolumn{3}{|c|}{$\mathrm{g} \mathrm{kg}^{-1}$} & \\
\hline M0 & $139.0 \pm 9.81 \mathrm{~b}$ & $98.6 \pm 9.42 \mathrm{a}$ & $7.3 \pm 0.65 \mathrm{a}$ & $6.0 \pm 0.76 \mathrm{a}$ & $14.0 \pm 0.87 \mathrm{~b}$ & $64.8 \mathrm{a}$ \\
\hline M1/2 & $167.9 \pm 3.70 \mathrm{a}$ & $42.4 \pm 3.51 \mathrm{~b}$ & $3.1 \pm 0.17 \mathrm{bc}$ & $4.6 \pm 0.76 \mathrm{a}$ & $20.5 \pm 0.53 \mathrm{a}$ & $72.2 \mathrm{a}$ \\
\hline M1 & $144.6 \pm 8.09 \mathrm{~b}$ & $45.6 \pm 2.37 \mathrm{~b}$ & $3.5 \pm 0.20 \mathrm{~b}$ & $6.0 \pm 0.55 \mathrm{a}$ & $21.5 \pm 0.46 \mathrm{a}$ & $73.0 \mathrm{a}$ \\
\hline M2 & $101.3 \pm 6.23 \mathrm{c}$ & $38.8 \pm 5.51 \mathrm{~b}$ & $2.3 \pm 0.12 \mathrm{c}$ & $3.9 \pm 0.57 \mathrm{~b}$ & $12.9 \pm 0.89 b$ & $53.1 \mathrm{~b}$ \\
\hline
\end{tabular}

M0, unmown; M1/2, mowing once every second year; M1, mowing once a year; M2, mowing twice a year. The value was the mean \pm S.E. $n=3$. WSOC, water soluble organic carbon. MBC, microbial biomass carbon. ROC, readily oxidized carbon. MHA, mobile humic acid. $\mathrm{CaHA}$, calcium humic acid. SOM, soil total organic matter. $\mathrm{HA}=\mathrm{MHA}+\mathrm{CaHA}$.

Compared with M0, M2 significantly decreased MHA content $(P<0.05)$ but did not affect CaHA content significantly $(P>0.05)$. However, M1 and M1/2 significantly increased CaHA content $(P<0.05)$ but did not significantly affect MHA content. Thus, both MHA and CaHA contents in soils of M1/2 and M1 were significantly higher than that in M2 $(P<0.05)$.

\subsection{Chemical structure of SOM}

Parameters of the elemental composition of the SOM were shown in Table 4 . The content of hydrogen $(\mathrm{H})$ and oxygen (O) varied from 0.49 to $0.63 \%$ and from 0.25 to $0.35 \%$, respectively. Compared with M0, all mowing treatments significantly decreased the $\mathrm{H}$ content, and $\mathrm{M} 2$ also significantly decreased $\mathrm{O}$ content $(P<0.05)$. The ratios of $\mathrm{H} / \mathrm{C}$ and $\mathrm{O} / \mathrm{C}$ varied from 0.13 to $0.16 \%$ and from 0.06 to $0.09 \%$, respectively, and the $\mathrm{H} / \mathrm{C}$ and $\mathrm{O} / \mathrm{C}$ ratios in M1/2 and M1 were significantly lower than M2 or M0 $(P<0.05)$.

The FTIR spectra of the SOM extracted from the grassland soil under different mowing treatments were shown in Fig. 1. The spectra were dominated by the broad peak around $3406 \mathrm{~cm}^{-1}$, sharp peaks around $1030 \mathrm{~cm}^{-1}$ and medium sharp peaks around $1653 \mathrm{~cm}^{-1}$, which were ascribed to $\mathrm{O}-\mathrm{H}$ stretching in alcohols, carboxylic acids and phenols, $\mathrm{C}-\mathrm{OH}$ stretching in carbohydrates, and $\mathrm{C}=\mathrm{C}$ stretching in aromatics, respectively. The intensity of other peaks in the FTIR spectra was relatively low. Small peaks at 2928 and closing to $1500 \mathrm{~cm}^{-1}$ due to aliphatic $\mathrm{C}-\mathrm{H}$ stretching in $\mathrm{CH}_{2} / \mathrm{CH}_{3}$

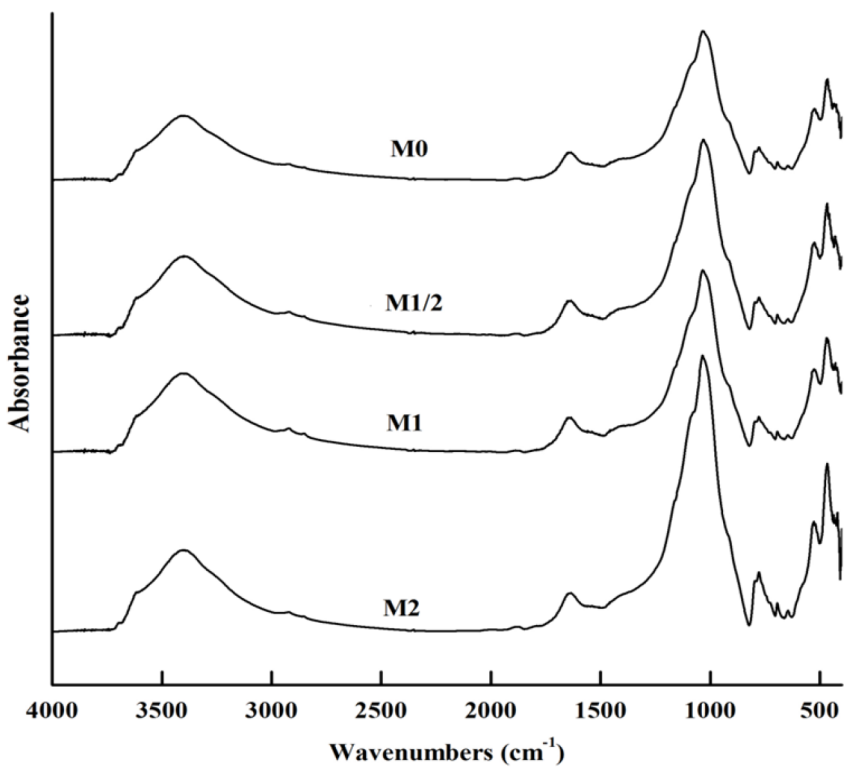

Figure 1. FTIR spectra of bulk SOM under different long-term mowing managements.

and amide $\mathrm{N}-\mathrm{C}$ / amino- $\mathrm{NH}$ vibrations, and aliphatic $\mathrm{C}-\mathrm{H}$ bending in $\mathrm{CH}_{2} / \mathrm{CH}_{3}$, respectively, were found in all treatments. However, only some small differences in the intensity of the peaks shown in the FTIR spectra were shown qualitatively between different treatments. The intensity of the peak at $2928 \mathrm{~cm}^{-1}$ in M1 was stronger than that in M0 and 
Table 4. Elemental composition of SOM from surface soils in grassland soil with different mowing frequencies.

\begin{tabular}{lrrrr|r|r}
\hline \multirow{2}{*}{ Treatment } & \multicolumn{4}{c|}{ Elemental composition, \% } & \multicolumn{2}{c}{ Atom ratios } \\
\cline { 2 - 7 } & $\mathrm{C}$ & $\mathrm{H}$ & $\mathrm{N}$ & $\mathrm{O}$ & $\mathrm{H} / \mathrm{C}$ & $\mathrm{O} / \mathrm{C}$ \\
\hline M0 & $3.94 \pm 0.03 \mathrm{~b}$ & $0.63 \pm 0.01 \mathrm{a}$ & $0.38 \pm 0.01 \mathrm{~b}$ & $0.35 \pm 0.02 \mathrm{a}$ & $0.16 \mathrm{a}$ & $0.09 \mathrm{a}$ \\
M1/2 & $3.95 \pm 0.04 \mathrm{~b}$ & $0.51 \pm 0.02 \mathrm{~b}$ & $0.39 \pm 0.01 \mathrm{~b}$ & $0.28 \pm 0.02 \mathrm{ab}$ & $0.13 \mathrm{~b}$ & $0.07 \mathrm{~b}$ \\
M1 & $4.32 \pm 0.05 \mathrm{a}$ & $0.56 \pm 0.02 \mathrm{~b}$ & $0.41 \pm 0.02 \mathrm{a}$ & $0.26 \pm 0.01 \mathrm{ab}$ & $0.13 \mathrm{~b}$ & $0.06 \mathrm{~b}$ \\
M2 & $3.28 \pm 0.03 \mathrm{c}$ & $0.49 \pm 0.01 \mathrm{~b}$ & $0.27 \pm 0.02 \mathrm{c}$ & $0.25 \pm 0.02 \mathrm{~b}$ & $0.15 \mathrm{a}$ & $0.08 \mathrm{a}$ \\
\hline
\end{tabular}

M0, unmown; M1/2, mowing once every second year; M1, mowing once a year; M2, mowing twice a year. The value was the mean \pm S.E., $n=3$.

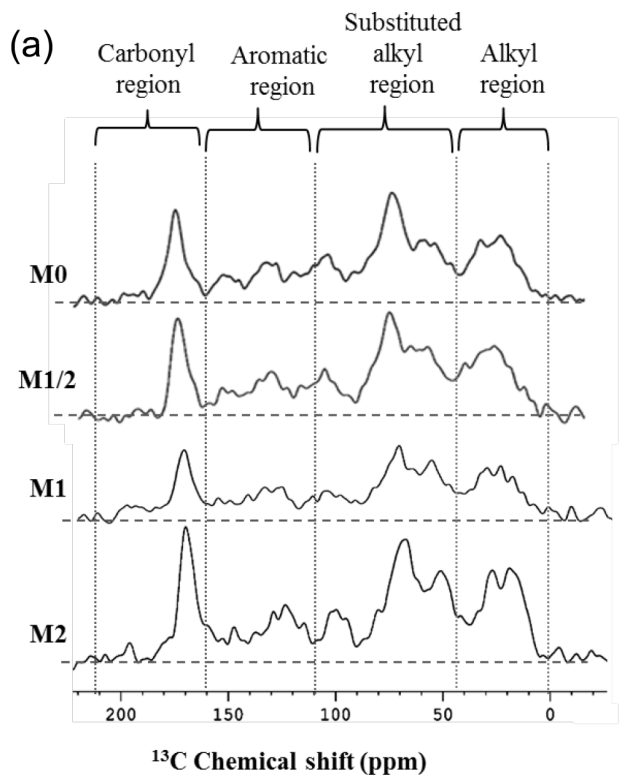

(b)

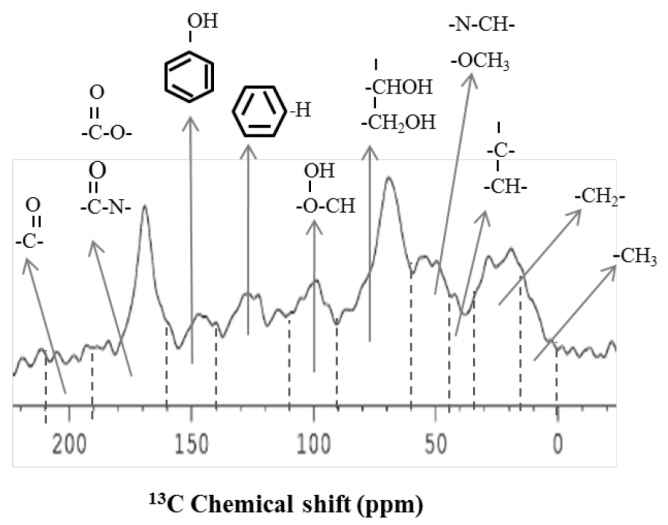

Figure 2. CPMAS ${ }^{13} \mathrm{C}$-NMR spectra of $10 \%$ HF pretreated SOM. (a) CPMAS ${ }^{13} \mathrm{C}$-NMR spectra of $10 \%$ HF pretreated SOM under different long-term mowing managements. (b) Detailed $\mathrm{C}$ functional groups in different chemical shifts.

M2, while the intensity of the peak at $1030 \mathrm{~cm}^{-1}$ in M1 was weaker than that in M0 and M2 treatments (Fig. 1 and Table 3).

Figure 2 showed the ${ }^{13} \mathrm{C}-\mathrm{NMR}$ spectra of the SOM extracted from the grassland soil with different mowing managements (Fig. 2a) and the detailed $\mathrm{C}$ functional groups represented by the peaks in the ${ }^{13} \mathrm{C}-\mathrm{NMR}$ spectra (Fig. 2b) were shown. In all spectra, the alkyl C (45-0 ppm) and substituted alkyl C (110-45 ppm) peaks were dominant components in SOC composition across all the treatments, accounting for $24.6-27.9$ and $41.5-47.6 \%$ of the total spectral fractions, respectively (Table 5 and Fig. 2), followed by aromatic C (165-110 ppm) and carbonyl C (210-165 ppm) peaks, accounting for $16.3-19.1$ and $9.3-13.7 \%$ of the total spectral fractions, respectively. In the substituted alkyl C, $O$ alkyl C (90-60 ppm) was the main fraction, making up more than $50 \%$ of the substituted alkyl C, while di- $O$-alkyl (110$90 \mathrm{ppm}$ ) only accounted for less than $21 \%$ of the substituted alkyl $\mathrm{C}$, and $N$-alkyl/methoxy $\mathrm{C}$ was medium. Compared to $\mathrm{M} 0$, mowing significantly increased alkyl $\mathrm{C}$ but significantly decreased substituted alkyl C (except for $N$-alkyl/methoxyl $\mathrm{C}, P<0.05$ ) mainly existing in carbohydrates (Table S1). The proportion of aromatic C (aryl and $O$-aryl C, 165$110 \mathrm{ppm}$ ) in M1/2 and M1 was significantly higher than that in M0, while the proportion of carbonyl C (210-165 ppm) in these two treatments was significantly lower than that in $\mathrm{M} 0$ $(P<0.05)$. Among mowing treatments, alkyl $\mathrm{C}$, substituted $\mathrm{C}$ and aryl $\mathrm{C}$ in $\mathrm{M} 2$ were significantly lower than those in $\mathrm{M} 1 / 2$ and M1, while $O$-aryl C and carbonyl C in M2 were significantly higher than those in $\mathrm{M} 1 / 2$ and $\mathrm{M} 1(P<0.05)$. The $O$-alkyl C in M2 was the lowest among all treatments, which was also consistent with the results of FTIR.

Soil ${ }^{13} \mathrm{C}-\mathrm{NMR}$ indices reflecting soil quality directly or indirectly were calculated and the results were shown in Table 6. Soil lignin C, the A / OA ratio and the $\mathrm{HB} / \mathrm{HI}$ ratio in M0 were significantly lower than those in the mowing treatments $(P<0.05)$, while the $\mathrm{CC} / \mathrm{MC}$ ratio in M0 was significantly higher than that in mowing treatments $(P<0.05)$. Aliphaticity in M1/2 and M1 was significantly lower than that in M0 and M2, while aromaticity was just the opposite 
Table 5. Percentages of total special spectral areas of different functional groups obtained by quantitative CPMAS ${ }^{13} \mathrm{C}-\mathrm{NMR}$ for soil samples from grassland soil with different mowing frequencies $(\%)$.

\begin{tabular}{lr|rrr|rr|r}
\hline & Alkyl C & \multicolumn{2}{|c|}{ Substituted alkyl C } & Aromatics & Carbonyls \\
\cline { 2 - 8 } Treatment & $\begin{array}{r}45-0 \mathrm{ppm} \\
\text { Alkyl }\end{array}$ & \begin{tabular}{r} 
60-45 -alkyl/methoxyl \\
\cline { 2 - 7 }
\end{tabular} & $\begin{array}{r}\text { 90-60 ppm } \\
O \text {-alkyl }\end{array}$ & $\begin{array}{r}110-90 \mathrm{ppm} \\
\text { di- } O \text {-alkyl }\end{array}$ & $\begin{array}{r}140-110 \mathrm{ppm} \\
\text { Aryl }\end{array}$ & $\begin{array}{r}165-140 \mathrm{ppm} \\
O \text {-aryl }\end{array}$ & $\begin{array}{r}210-165 \mathrm{ppm} \\
\text { Carboxyl and carbonyl }\end{array}$ \\
\hline M0 & $24.6 \pm 0.12 \mathrm{c}$ & $11.2 \pm 0.06 \mathrm{c}$ & $27.0 \pm 0.17 \mathrm{a}$ & $9.4 \pm 0.06 \mathrm{a}$ & $11.7 \pm 0.08 \mathrm{~b}$ & $4.6 \pm 0.04 \mathrm{c}$ & $11.1 \pm 0.17 \mathrm{~b}$ \\
M1/2 & $27.6 \pm 0.20 \mathrm{a}$ & $12.9 \pm 0.05 \mathrm{~b}$ & $22.5 \pm 0.06 \mathrm{~b}$ & $8.6 \pm 0.09 \mathrm{~b}$ & $13.4 \pm 0.09 \mathrm{a}$ & $5.7 \pm 0.06 \mathrm{~b}$ & $9.3 \pm 0.06 \mathrm{c}$ \\
M1 & $27.9 \pm 0.23 \mathrm{a}$ & $13.4 \pm 0.06 \mathrm{a}$ & $22.3 \pm 0.15 \mathrm{~b}$ & $8.1 \pm 0.06 \mathrm{c}$ & $13.6 \pm 0.06 \mathrm{a}$ & $5.6 \pm 0.06 \mathrm{~b}$ & $9.1 \pm 0.06 \mathrm{c}$ \\
M2 & $25.4 \pm 0.12 \mathrm{~b}$ & $12.3 \pm 0.25 \mathrm{bc}$ & $21.7 \pm 0.09 \mathrm{c}$ & $7.5 \pm 0.07 \mathrm{c}$ & $11.8 \pm 0.12 \mathrm{~b}$ & $6.6 \pm 0.07 \mathrm{a}$ & $14.7 \pm 0.15 \mathrm{a}$ \\
\hline
\end{tabular}

M0, unmown; M1/2, mowing once every second year; M1, mowing once a year; M2, mowing twice a year. The value was the mean \pm S.E., $n=3$.

Table 6. CPMAS ${ }^{13} \mathrm{C}-\mathrm{NMR}$ indices of SOM from surface soils in grassland soils with different mowing frequencies.

\begin{tabular}{|c|c|c|c|c|c|c|c|c|c|}
\hline \multirow[t]{2}{*}{ Treatment } & Lingin-C & Polysaccharide-C & \multirow[t]{2}{*}{$\mathrm{L} / \mathrm{P}$} & Aliphaticity & Aromaticity & \multirow[t]{2}{*}{$\mathrm{Al} / \mathrm{Ar}$} & \multirow[t]{2}{*}{$\mathrm{A} / \mathrm{OA}$} & \multirow[t]{2}{*}{$\mathrm{HB} / \mathrm{HI}$} & \multirow[t]{2}{*}{$\mathrm{CC} / \mathrm{MC}$} \\
\hline & \multicolumn{2}{|c|}{$\%$ of SOC } & & \multicolumn{2}{|c|}{$\%$} & & & & \\
\hline M0 & $36.4 \mathrm{c}$ & $13.9 \mathrm{~b}$ & $2.61 \mathrm{~b}$ & $79.3 \mathrm{a}$ & $20.7 \mathrm{c}$ & $3.84 \mathrm{a}$ & $0.91 \mathrm{~b}$ & $0.76 \mathrm{~b}$ & $2.23 \mathrm{a}$ \\
\hline $\mathrm{M} 1 / 2$ & $38.6 \mathrm{~b}$ & $16.7 \mathrm{a}$ & $2.30 \mathrm{c}$ & $78.9 \mathrm{~b}$ & $21.1 \mathrm{~b}$ & $3.74 \mathrm{~b}$ & $1.23 \mathrm{a}$ & $0.88 \mathrm{a}$ & $1.74 \mathrm{~b}$ \\
\hline M1 & $38.2 \mathrm{~b}$ & $16.9 \mathrm{a}$ & $2.26 \mathrm{c}$ & $78.5 \mathrm{c}$ & $21.5 \mathrm{a}$ & $3.65 \mathrm{c}$ & $1.25 \mathrm{a}$ & $0.87 \mathrm{a}$ & $1.66 \mathrm{c}$ \\
\hline M2 & $42.0 \mathrm{a}$ & $14.2 \mathrm{~b}$ & $2.97 \mathrm{a}$ & $79.4 \mathrm{a}$ & $20.6 \mathrm{c}$ & $3.85 \mathrm{a}$ & $1.17 \mathrm{~b}$ & $0.81 \mathrm{ab}$ & $1.76 \mathrm{~b}$ \\
\hline
\end{tabular}

M0, unmown; M1/2, mowing once every second year; M1, mowing once a year; M2, mowing twice a year. L/P, lignin / polysaccharide. A / OA, alkyl C / $O$-alkyl C. $\mathrm{HB}$ / HI, hydrophobic C / hydrophilic C. CC / MC, carbohydrate C / methoxyl C. Al / Ar, aliphaticity / aromaticity.

$(P<0.05)$, which resulted in an $\mathrm{Al} / \mathrm{Ar}$ ratio in $\mathrm{M} 1 / 2$ and $\mathrm{M} 1$ that was significantly lower than that in M0. There was no difference in aliphaticity, aromaticity and $\mathrm{Al} / \mathrm{Ar}$ ratios between M0 and M2 $(P>0.05)$. Among different mowing treatments, most of the ${ }^{3} \mathrm{C}-\mathrm{NMR}$ indices in $\mathrm{M} 1 / 2$ are similar to M1, except that aromaticity in M1/2 was significantly lower than that in M1, while aliphaticity and the CC / MC ratio in $\mathrm{M} 1 / 2$ were significantly higher than those in $\mathrm{M} 1$ $(P<0.05)$. In all of the indices, lignin $\mathrm{C}$, the $\mathrm{L} / \mathrm{P}$ ratio and aliphaticity in $\mathrm{M} 2$ were significantly higher than those in both M1/2 and M1, and the other indices were the opposite $(P<0.05)$.

\subsection{Variations of SOM fraction and the $\mathrm{C}$ functional group in relation to $\mathrm{SOM}$ mineralization and microbial characterization}

Soil organic matter content was significantly and positively correlated with MBC, MHA, CaHA and net $\mathrm{N}$ mineralization with $r=0.45,0.48,0.89$, and $0.54(P<0.05)$, but was not correlated with WSOC and ROC $(P>0.05)$ (Table 7). ROC was significantly correlated with WSOC, MBC, MHA, CaHA and net $\mathrm{N}$ mineralization $(r=0.55-0.92, P<0.05)$ and MHA was significantly correlated with $\mathrm{CaHA}(r=0.82$, $P<0.05)$. Moreover, positive correlations were found between net $\mathrm{N}$ mineralization and MBC, MHA, and CaHA, with $r=0.60,0.83$, and 0.75 , respectively $(P<0.05)$.

The relationships between net $\mathrm{N}$ mineralization or MBC and the $\mathrm{C}$ functional groups of SOC were shown in Table 8 . The results showed that $\mathrm{N}$ mineralization was related to the chemical structure of SOC and to microbial biomass. Net N mineralization was not significantly related to four detailed CPMAS ${ }^{13} \mathrm{C}$-NMR regions $(N$-alkyl/methoxyl C, $O$-alkyl $\mathrm{C}$, di- $O$-alkyl $\mathrm{C}$ and aryl C), with $r=0.28,0.37,0.47$ and -0.24 , respectively $(P>0.05)$, but was negatively correlated with $O$-aryl C $(r=-0.94, P<0.001)$ and carbonyl C $(r=-0.79, P<0.01)$ and the integrated aromatics including aryl $\mathrm{C}$ and $O$-aryl $\mathrm{C}(r=-0.81, P<0.01)$. Consistent with net $\mathrm{N}$ mineralization, significant negative correlations were also found between $\mathrm{MBC}$ and $O$-aryl C $(r=-0.84$, $P<0.001)$, carbonyl C $(r=-0.96, P<0.01)$ and the integrated aromatics $(r=-0.39, P<0.05)$. However, both net $\mathrm{N}$ mineralization and $\mathrm{MBC}$ were positively correlated with alkyl C, with $r=0.46$ and 0.59 , respectively $(P<0.05)$. Different from net $\mathrm{N}$ mineralization, $\mathrm{MBC}$ was also significantly correlated with di- $O$-alkyl C and aryl C, with $r=0.59$ and $0.73(P<0.05)$, respectively, but was not correlated with $N$-alkyl/methoxyl C and $O$-alkyl C.

\section{Discussion}

\subsection{SOM accumulation impacted by different mowing practices for the long term}

Our results showed that 12 -year M1/2 and M1 significantly enhanced SOM accumulation and increased the soil TN content (Table 2), which agreed with previous studies (Cong et al., 2014). Mowing (M1) enhanced plant species by increasing the subordinate plants (Mariotte et al., 2015; Socher et 
Table 7. Linear correlation coefficients for relationships among different SOM fractions and net N mineralization.

\begin{tabular}{|c|c|c|c|c|c|c|c|}
\hline & SOC & WSOC & $\mathrm{MBC}$ & ROC & MHA & $\mathrm{CaHA}$ & $\begin{array}{r}\text { Net N } \\
\text { mineralization }\end{array}$ \\
\hline SOC & 1 & & & & & & \\
\hline WSOC & 0.11 & 1 & & & & & \\
\hline MBC & 0.45 & 0.37 & 1 & & & & \\
\hline ROC & 0.36 & 0.90 & 0.55 & 1 & & & \\
\hline MHA & 0.48 & 0.43 & 0.45 & 0.92 & 1 & & \\
\hline $\mathrm{CaHA}$ & 0.89 & 0.41 & 0.34 & 0.81 & 0.82 & 1 & \\
\hline Net $\mathrm{N}$ mineralization & 0.54 & 0.08 & 0.60 & 0.91 & 0.83 & 0.75 & 1 \\
\hline
\end{tabular}

Table 8. Summary of the linear correlation for relationships between net $\mathrm{N}$ mineralization, $\mathrm{MBC}$ and all the $\mathrm{C}$ functional groups of SOC determined by CPMAS ${ }^{13} \mathrm{C}-\mathrm{NMR}$.

\begin{tabular}{|c|c|c|c|c|}
\hline \multirow[t]{2}{*}{ Chemical shifts, region (ppm) } & \multicolumn{2}{|c|}{ Net $\mathrm{N}$ mineralization } & \multicolumn{2}{|c|}{$\mathrm{MBC}$} \\
\hline & $r$ & $P$ & $r$ & $P$ \\
\hline \multicolumn{5}{|l|}{ Detail assignments } \\
\hline Alkyl C (45-0) & 0.46 & 0.047 & 0.59 & 0.039 \\
\hline$N$-alkyl/methoxyl C (60-45) & 0.28 & 0.615 & 0.29 & 0.891 \\
\hline$O$-alkyl C (90-60) & 0.37 & 0.429 & 0.27 & 0.992 \\
\hline di- $O$-alkyl C (110-90) & 0.47 & 0.326 & 0.59 & 0.027 \\
\hline Aryl C (140-110) & -0.24 & 0.798 & 0.73 & 0.011 \\
\hline$O$-aryl C (165-140) & -0.94 & $<0.001$ & -0.84 & $<0.001$ \\
\hline Carbonyl C (210-165) & -0.79 & 0.005 & -0.96 & 0.003 \\
\hline \multicolumn{5}{|l|}{ Integrated regions } \\
\hline Unsubstituted alkyl C (45-0) & - & - & - & - \\
\hline Substituted alkyl C (110-45) & 0.70 & 0.010 & 0.68 & 0.014 \\
\hline Aromatics $(165-110)$ & -0.81 & 0.008 & -0.39 & 0.042 \\
\hline Carbonyls (210-165) & - & - & - & - \\
\hline
\end{tabular}

al., 2012). Enhanced plant species richness promoted plant productivity and photosynthesis, and thus increased soil carbon and nitrogen stocks in grasslands by more input of organic $\mathrm{C}$ and $\mathrm{N}$ derived from more root biomass, root exudates and $\mathrm{N}$ retention and photosynthetic products (Cong et al., 2014; Gao et al., 2008), which further had a positive feedback to plant productivity, including legume. Legume was common in grassland and moderate mowing would stimulate its productivity to increase atmospheric $\mathrm{N}$ fixation (Cardinale et al., 2012), and $\mathrm{N}$ enrichment benefited $\mathrm{C}$ accumulation, in turn (Riggs and Hobbie, 2016). In addition, the significant increase in CaHA content in M1/2 and M1 was the main and direct reason for SOM accumulation, as the CaHA was the dominant fraction of SOM (Table 3), which indicated that M1/2 and M1 enhanced the humus formation. Moderate mowing increased the fungal community abundance and diversity (Li et al., 2017), and it was reported that fungi could make the molecular structure of humus more complex $(\mathrm{Li}$, 2012).
Compared to moderate mowing, long-term excessive mowing practice resulted in herbage productivity decline due to high nutrient removal from the soil and plant species reduction (Baoyin et al., 2014), which would result in the decrease in labile SOM fractions (WSOC, MBC and ROC) and relatively labile $\mathrm{C}$ (MHA) contents in $\mathrm{M} 2$. Microbes were sensitive to perturbation and thus $\mathrm{MBC}$ was regarded as a reliable indicator of the change in SOC pools caused by management practices (Fang et al., 2009). The significant reduction of MBC content was the key biotic reason for soil net $\mathrm{N}$ mineralization reduction (Table 4). Therefore, long-term M2 treatment hampered the soil nutrient cycling and balance, and should be avoided.

\subsection{Stability of SOM impacted by different mowing treatments}

Different mowing treatments had diverse impacts on the chemical structure of SOM. The composition of SOM chemical structure directly reflected the stability of SOM and thus informed the degradability of SOM. The elemental analysis suggested that long-term mowing practice had major impacts on the elemental composition of SOM. The lower $\mathrm{H} / \mathrm{C}$ ratio indicated more aromatic compounds or higher aromaticity and saturability, and the higher $\mathrm{O} / \mathrm{C}$ ratio indicated more carboxyl groups, phenol or carbohydrates with oxygen $(\mathrm{Ma}$ et al., 2001; Steelink, 1985; Kim et al., 1991). ${ }^{13} \mathrm{C}$ NMR apparently differentiated the lignin $\mathrm{C}$ (including alkyl, $\mathrm{N}$-alkyl and aryl $\mathrm{C}$ ) and carbohydrate $\mathrm{C}$ (including $O$-alkyl, di- $O$ alkyl, carbonyl and carboxyl C) (Hu et al., 2017). Therefore, both elemental analysis and the quantified analysis of ${ }^{13} \mathrm{C}$ NMR spectra showed that M1/2 and M1 led to a significant loss of the carbohydrates and accumulation of lignin by more litter input, which indicated that M1/2 and M1 benefited the stability of SOM. Previous studies also reported that aryl C at 140-110 ppm was rich in condensed aromatics and was quite stable in the soil, and its content could reflect the stability of C pools (Zhou et al., 2014). According to this conclusion, M2 had little influence on the stability of SOM. However, the highest content of carbonyl and carboxyl C in M2 suggested 
that SOM in M2 was not stable, as compounds that included carbonyl and carboxyl $\mathrm{C}$ could be degraded relatively easily.

The accumulation of lignin and the increase in microbial biomass were the favourable conditions of humification. Therefore, the CaHA fraction in SOM increased by 46.9$52.5 \%$ after 12-year M1/2 and M1. This suggested that longterm moderate mowing managements enhanced the degree of humification of SOM. By contrast, the reduction of litter input and the significantly decreased microbial biomass in M2 led to the reduction of humus. Zech et al. (1997) also documented that excessive human activity resulted in the humic horizons' disappearance in many tropical regions. This suggested that M2 hindered SOM humification and disturbed the SOM balance, which might be because the plant diversity and productivity were limited (Socher et al., 2012; Mariotte et al., 2013), resulting in lower labile carbon content and less soil microbial function (Steinauer et al., 2015).

In the CPMAS ${ }^{13} \mathrm{C}-\mathrm{NMR}$ indices (Table 7), the A / OA (alkyl $\mathrm{C} / O$-alkyl $\mathrm{C}$ ) ratio is generally taken as a sensitivity index for characterizing the decomposing extent of SOM (Baldock et al., 1997). When the value of the A/OA ratio is relatively high, it indicates that the degree of decomposition of SOM is high. In general, alkyl $\mathrm{C}$ and $O$-alkyl C keep a trade-off relationship (Li et al., 2013). The higher A / OA ratio in M1/2 and $M 1$ could be because SOM in M1/2 and M1 was difficult to decompose further (Zhao et al., 2012). Therefore, moderate mowing (M1/2 and M1) enhanced the accumulation of stable fractions of SOM and recalcitrant chemical structures of SOC, and primed the degradation of labile $\mathrm{C}$, which suggested that moderate mowing benefited the $\mathrm{C}$ stable sequestration in the semiarid grassland, which was significant to the grassland $\mathrm{C}$ pool. This foundation was reported for the first time in the grassland ecosystem. The carbohydrate $\mathrm{C}$ / methoxyl $\mathrm{C}$ (CC / $\mathrm{MC}$ ) ratio is a new indicator to reflect the degree of degradation of SOM (Mathers et al., 2007), and both CC / MC and A / OA ratios showed that the degradation degree of SOM in M1 was the maximum. In addition to the highest CaHA content and highest herbage productivity in M1, M1 was the superior mowing management practice. The aliphaticity / aromaticity ( $\mathrm{Al} / \mathrm{Ar}$ ) ratio is a predictor to reveal the complexity of the chemical composition of SOM, and the higher the value, the simpler the chemical composition of SOC. The hydrophobic $\mathrm{C} /$ hydrophilic $\mathrm{C}$ (HB / HI) ratio was used as a measure of $\mathrm{C}$ chemical recalcitrance, and the higher this value, the more stable the SOM (Boeni et al., 2014). The increased HB / HI ratios in M1/2 and M1 treatments showed that SOM was more recalcitrant to being mineralized. Meanwhile, the $\mathrm{Al} / \mathrm{Ar}$ ratio revealed that M1/2 and M1 increased the chemical composition complexity of SOM, while M2 had no effect on either the chemical recalcitrance or complexity of SOM. These further proved that M1/2 and M1 improved the stability of SOM. The higher alkyl C in M1/2 and M1 is closely associated with the increase in recalcitrant compounds (waxes, resin, cutin, suberin, peptide side-chain, long-chain aliphat- ics) (Table S1), mainly derived from the increased plant materials (Socher et al., 2012; Mariotte et al., 2013), accompanied by the loss of labile $\mathrm{C}$ such as carbohydrates and polysaccharides, and by the increase in lignin and cellular residues of microbes (Table 4). It is interesting that lignin C in treatment M2 was significantly higher than that in other treatments (Table 6), which might be because M2 limited the growth of degraders. In the future, it will be necessary to study the changes in functional microbial community in different mowing treatments using high throughput sequencing. Different from M1/2, M1 significantly increased $\mathrm{N}$ alkyl/methoxyl $\mathrm{C}$, which was recalcitrant $\mathrm{C}$, and it was relatively enriched in topsoil when $O$-alkyl or di- $O$-alkyl C was prone to oxidation. In terms of the stability of SOM, M1 was the optimized mowing management practice.

\subsection{Relationship among net $\mathrm{N}$ mineralization, microbes and chemical compositions of SOM}

In natural grasslands, SOM mainly comes from plant litter, roots and soil microbial cellular residues, ca. $2-15 \%$ of which was constituted by the N-containing compounds, such as amino acids, amino sugar, pyrimidines, purines or porphyrin (Mathers et al., 2007). Therefore, close correlations among the four $\mathrm{C}$ functional groups, net $\mathrm{N}$ mineralization and $\mathrm{MBC}$ were also observed, and $\mathrm{MBC}$ was significantly related to both $\mathrm{C}$ functional groups and net $\mathrm{N}$ mineralization (Tables 8 and 9), which suggested that microorganisms were the driving force of soil $\mathrm{C}$ and $\mathrm{N}$ turnover in the semiarid natural grassland. Li et al. (2017) reported that fungi might have played a more important role than bacteria in the $\mathrm{N}$ mineralization in the semiarid Inner Mongolia grassland, as fungi could better bear the drought and poor available nutrient conditions (Andresen et al., 2014; Mariotte et al., 2015). We also found that the correlation between $\mathrm{C}$ functional groups and MBC was consistent with that between $\mathrm{C}$ functional groups and net $\mathrm{N}$ mineralization. Stevenson et al. (2016) concluded that soils relatively rich in $\mathrm{N}$ should also be relatively rich in alkyl $\mathrm{C}$, and the chemical composition of SOM significantly influenced soil $\mathrm{N}$ mineralization.

Similar to forest soil, recalcitrant $\mathrm{C}$ (alkyl $\mathrm{C}$ and aromatic C) also accounted for a large proportion of the SOC in the grassland soil. In our study, alkyl and aromatic $\mathrm{C}$ accounted for $40.9-47.1 \%$ of all functional C. It was reported that fungi played the key role in the decomposition of soil organic $\mathrm{N}$ in the forest ecosystem (Boeni et al., 2014; Li et al., 2013), which indicated that fungi might also be critically important for the degradation of organic $\mathrm{N}$ in the grassland ecosystem. Li et al. (2017) reported that mowing once a year increased fungal abundance and diversity, while a higher mowing frequency decreased them. The increased fungal communities were characterized by the function of mineralizing SOM and activating nutrients. In the semiarid grassland, the contents of soil rapidly available $\mathrm{N}$ and available $\mathrm{P}$ were very low, and mycorrhizal fungi were richer in M1. Northup et 
al. (1998) found a mechanism by which plant productivity could be sustained through mycorrhizal fungi by investigating plant-soil-microbe interaction. M1/2 and M1 improved herbage productivity and thus increased net SOC content mainly by increasing recalcitrant $\mathrm{C}$, and further increased microbial community diversity and dominant microbial community abundance. In turn, the increased microbial community enhanced the labile SOM degradation and the humification of SOM to make the chemical composition of SOM more stable, and this agreed with the studies conducted by Baumann et al. (2013) and Zhang et al. (2015). Thus, the relationship between chemical composition of SOM, SOM mineralization and the microbial community would give us a better understanding of the stability of soil $\mathrm{C}$ and $\mathrm{N}$ pools.

\section{Conclusions}

Long-term M1/2 and M1 treatments significantly enhanced the accumulation of SOM by increasing the CaHA content and lignin, while the higher-frequency mowing practice (M2) limited the accumulation of SOM. Mowing had significant impacts on the fractions and chemical structure of SOM. M1/2 and M1 significantly increased soil CaHA and MBC content and improved the stability of SOM by increasing alkyl $\mathrm{C}$ and aromatic $\mathrm{C}$ functional groups, which suggested that the humification was enhanced, while higher-frequency mowing practice (M2) had a negative impact on the stability of SOM. Therefore, M1/2 and M1 were considered moderate mowing practices, while M2 should be avoided from a long-term perspective. M1 was the best mowing practice because it increased the stability of SOM by elevating a stable chemical structure of SOM and enhancing the humification of SOM. In addition, the ${ }^{13} \mathrm{C}-\mathrm{NMR}$ indices could consistently reflect the stability of SOM. The impacts of mowing on the accumulation and stability of SOM were closely related to soil microbes and SON mineralization. Moderate mowing managements were beneficial for more microbes to degrade the labile SOM to provide $\mathrm{N}$ for plant growth, and this increased the SOM input in turn. Solid CPMAS ${ }^{13} \mathrm{C}-\mathrm{NMR}$ is a powerful technique assessing the complex samples, e.g. soil, and it showed that alkyl $\mathrm{C}$ and $O$-alkyl $\mathrm{C}$ were the dominant chemical components of grassland SOC under different mowing treatments, followed by aromatic $\mathrm{C}$ and carbonyl $\mathrm{C}$. However, to better understand the biological mechanisms of SOM chemical shifts resulting from different mowing managements, it is necessary to further investigate the microbial community diversity and the relationship between the $\mathrm{C}$ functional groups and microbial community diversity by combining advanced NMR and high-throughput sequencing techniques.

Data availability. Data for this paper can be found in the Supplement.

\section{The Supplement related to this article is available online at doi:10.5194/bg-14-2685-2017-supplement.}

Competing interests. The authors declare that they have no conflict of interest.

Acknowledgements. This work was financially supported by the National Key Basic Research Program of China (2014CB138801) and the National Natural Science Foundation of China (41271272 and 41401266).

Edited by: X. Wang

Reviewed by: two anonymous referees

\section{References}

Andresen, L. C., Dungait, J. A., Bol, R., Selsted, M. B., Ambus, P., and Michelsen, A.: Bacteria and fungi respond differently to multifactorial climate change in a temperate heathland, traced with ${ }^{13} \mathrm{C}$-glycine and FACE $\mathrm{CO}_{2}$, PLoS One 9, e85070, doi:10.1371/journal.pone.0085070, 2014.

Baldock, J. A., Oades, J. M., Nelson, P. N., Skene, T. M., Golchin, A., and Clarke, P.: Assessing the extent of decomposition of natural organic materials using solid-state ${ }^{13} \mathrm{C}$ NMR spectroscopy, Aust. J. Soil Res., 35, 1061-1083, doi:10.1071/S97004, 1997.

Bao, S. D.: Analytical Methods for Soil and Agricultural Chemistry, China Agriculture Science and Technology Press, Beijing, 2000 (in Chinese).

Baoyin, T., Li, F. Y., Bao, Q., Minggagud, H., and Zhong, Y. K.: Effects of mowing regimes and climate variability on hay production of Leymus chinensis (Trin.) Tzvelev grassland in northern China, Rangeland J., 36, 593-600, doi:10.1071/RJ13088, 2014.

Baumann, K., Marschner, P., Smernik, R. J., and Baldock, J. A.: Residue chemistry and microbial community structure during decomposition of eucalypt, wheat and vetch residues, Soil Biol. Biochem., 41, 1966-1975, doi:10.1016/j.soilbio.2009.06.022, 2009.

Baumann, K., Dignac, M. F., Rumpel, C., Bardoux, G., Sarr, A., Steffens, M., and Maron, P. A.: Soil microbial diversity affects soil organic matter decomposition in a silty grassland soil, Biogeochemistry, 114, 201-212, doi:10.1007/s10533-012-9800-6, 2013.

Baumann, K., Schöning, I., Schrumpf, M., Ellerbrock, R. H., and Leinweber, P.: Rapid assessment of soil organic matter: Soil color analysis and Fourier transform infrared spectroscopy, Geoderma, 278, 49-57, doi:10.1016/j.geoderma.2016.05.012, 2016.

Boeni, M., Bayer, C., Dieckow, J., Conceição, P. C., Dick, D. P., Knicker, H., and Macedo, M. C. M.: Organic matter composition in density fractions of Cerrado Ferralsols as revealed by CPMAS ${ }^{13} \mathrm{C}$ NMR: Influence of pastureland, cropland and integrated crop-livestock, Agr. Ecosyst. Environ., 190, 80-86, doi:10.1016/j.agee.2013.09.024, 2014.

Bonanomi, G., Incerti, G., Giannino, F., Mingo, A., Lanzotti, V., and Mazzoleni, S.: Litter quality assessed by solid state ${ }^{13} \mathrm{C}$ NMR spectroscopy predicts decay rate better than 
C / N and Lignin / N ratios, Soil Biol. Biochem., 56, 40-48, doi:10.1016/j.soilbio.2012.03.003, 2013.

Bremner, J. M.: Total nitrogen, in: Methods of Soil Analysis, Part 2. American Society of Agronomy, edited by: Black, C. A., Madison, 1149-1178, 1965.

Cao, X., Olk, D. C., Chappell, M., Cambardella, C. A., Miller, L. F., and Mao, J.: Solid-state NMR analysis of soil organic matter fractions from integrated physical-chemical extraction, Soil Sci. Soc. Am. J., 75, 1374-1384, doi:10.2136/sssaj2010.0382, 2011.

Cardinale, B. J., Duffy, J. E., Gonzalez A., Hooper, D. U., Perrings, C., Venail, P., and Kinzig, A. P.: Biodiversity loss and its impact on humanity, Nature, 486, 59-67, doi:10.1038/nature11148, 2012.

Chen, Z., Wang, H., Liu, X., Zhao, X., Lu, D., Zhou, J., and $\mathrm{Li}, \mathrm{C} .:$ Changes in soil microbial community and organic carbon fractions under short-term straw return in a rice-wheat cropping system, Soil Till. Res., 165, 121-127, doi:10.1016/j.still.2016.07.018, 2017.

Cong, W., van Ruijven, J., Mommer, L., De Deyn, G. B., Berendse, F., and Hoffland, E.: Plant species richness promotes soil carbon and nitrogen stocks in grasslands without legumes, J. Ecol., 102, 1163-1170, doi:10.1111/1365-2745.12280, 2014

Dijkstra, F. A., Hobbie, S. E., Reich, P. B., and Knops, J. M.: Divergent effects of elevated $\mathrm{CO}_{2}, \mathrm{~N}$ fertilization, and plant diversity on soil $\mathrm{C}$ and $\mathrm{N}$ dynamics in a grassland field experiment, Plant Soil, 272, 41-52, doi:10.1007/s11104-004-3848-6, 2005.

Fang, H. J., Yu, G. R., Cheng, S. L., Mo, J. M., Yan, J. H., and Li, S.: $\mathrm{C}$ abundance, water-soluble and microbial biomass carbon as potential indicators of soil organic carbon dynamics in subtropical forests at different successional stages and subject to different nitrogen loads, Plant Soil, 320, 243-254, doi:10.1007/s11104009-9890-7, 2009.

Fontaine, S., Henault, C., Aamor, A., Bdioui, N., Bloor, J. M. G., Maire, V., and Maron, P. A.: Fungi mediate long term sequestration of carbon and nitrogen in soil through their priming effect, Soil Biol Biochem., 43, 86-96, doi:10.1016/j.soilbio.2010.09.017, 2011.

Jiang, S.: Setting up the experimental sites for grassland ecosystem research and vegetation status, Res. Grassland Ecosyst., 3, 1-12, 1988 (in Chinese)

Gao, Y. Z., Giese, M., Lin, S., Sattelmacher, B., Zhao, Y., and Brueck, H.: Belowground net primary productivity and biomass allocation of a grassland in Inner Mongolia is affected by grazing intensity, Plant Soil, 307, 41-50, doi:10.1007/s11104-008-95793, 2008.

Hu, Z. H., Xu, C. G., McDowell, N. G., Johnson, D. G., Wang, M. H., Luo, Y. Q., Zhou, X. H., and Huang, Z. Q.: Linking microbial community composition to $\mathrm{C}$ loss rates during wood decomposition, Soil Biol. Biochem., 104, 108-116, doi:10.1016/j.soilbio.2016.10.017, 2017.

Kim, J. L., Buckau, G., Klenze, R., Rhee, D. S., and Wimmer, H.: Characterization and complexation of humic acids. Luxembourg, Nul. Sci. Tech., 9-10, 1991.

Kalembasa, S. J. and Jenkinson, D. S.: A comparative study of titrimetric and gravimetric methods for the determination of organic carbon in soil, J. Sci. Food Agr., 24, 1085-1090, doi:10.1002/jsfa.2740240910, 1973.

Knicker, H., Nikolova, R., Dick, D. P., and Dalmolin, R. S. D.: Alteration of quality and stability of organic mat- ter in grassland soils of Southern Brazil highlands after ceasing biannual burning, Geoderma, 181-182, 11-21, doi:10.1016/j.geoderma.2012.03.001, 2012.

Li, H. M.: The impact of different microorganisms on the number and structural characteristics of humic acid and humin, Master thesis, Changchun, Jilin Agriculture University, 2012 (in Chinese).

Li, J. Y., Zhang, Q. C., Li, Y., Liu, J., Pan, H., Guan, X. M., Xu, X. Y., Xu, J. M., and Di, H. J.: Impact of mowing management on nitrogen mineralization rate and fungal and bacterial communities in a semiarid grassland ecosystem, J. Soil. Sediment., 1-12, doi:10.1007/s11368-016-1620-1, 2017.

Li, Y., Jiang, P., Chang, S. X., Wu, J., and Lin, L.: Organic mulch and fertilization affect soil carbon pools and forms under intensively managed bamboo (Phyllostachys praecox) forests in southeast China, J. Soil. Sediment., 10, 739-747, doi:10.1007/s11368-010-0188-4, 2010.

Li, Y., Zhang, J., Chang, S. X., Jiang, P., Zhou, G., Fu, S., and Lin, L.: Long-term intensive management effects on soil organic carbon pools and chemical composition in Moso bamboo (Phyllostachys pubescens) forests in subtropical China, Forest Ecol. Manag., 303, 121-130, doi:10.1016/j.foreco.2013.04.021, 2013.

Lin, X. G.: Principles and methods of soil microbiology research. Beijing: Higher Education Press, China, 225 pp., 2010 (in Chinese).

Ma, H. Z., Allen, H. E., and Yin, Y. J.: Characterization of isolated fractions of dissolved organic matter from natural waters and a wastewater effluent, Water Res., 35, 985-996, doi:10.1016/S0043-1354(00)00350-X, 2001.

Mao, J. D., Olk, D. C., Fang, X. W., He, Z. Q., and Klaus, S. R.: Influence of animal manure application on the chemical structures of soil organic matter as investigated by advanced solidstate NMR and FTIR spectroscopy, Geoderma, 14, 353-362, doi:10.1016/j.geoderma.2008.06.003, 2008.

Mariotte, P., Vandenberghe, C., Meugnier, C., Rossi, P., Bardgett, R. D., and Buttler, A.: Subordinate plant species impact on soil microbial communities and ecosystem functioning in grasslands: findings from a removal experiment, Perspect. Plant. Ecol., 15, 77-85, doi:10.1016/j.ppees.2012.12.003, 2013.

Mariotte, P., Robroek, B. J., Jassey, V. E., and Buttler, A.: Subordinate plants mitigate drought effects on soil ecosystem processes by stimulating fungi, Funct. Ecol., 29, 1578-1586, doi:10.1111/1365-2435.12467, 2015.

Mathers, N. J., Jalota, R. K., Dalal, R. C., and Boyd, S. E.: ${ }^{13}$ CNMR analysis of decomposing litter and fine roots in the semiarid Mulga Lands of southern Queensland, Soil Biol. Biochem., 39, 993-1006, doi:10.1016/j.soilbio.2006.11.009, 2007.

The National Environment Protection Bureau of China: China's Environmental Bulletin, Beijing, 82-89, 2006 (in Chinese).

Northup, R. R., Dahlgren, R. A., and McColl, J. G.: Polyphenols as regulators of plant-litter-soil interactions in northern California's pygmy forest: a positive feedback?, Biogeochemistry, 42, 189220, doi:10.1023/A:1005991908504, 1998.

Olk, D. C.: A chemical fractionation for structure-function relations of soil organic matter in nutrient cycling, Soil Sci. Soc. Am. J., 70, 1013-1022, doi:10.2136/sssaj2005.0108, 2006.

Olk, D. C. and Gregorich, E. G.: Overview of the symposium proceedings, Meaningful pools in determining soil car- 
bon and nitrogen dynamics, Soil Sci. Soc. Am. J., 70, 967-974, doi:10.2136/sssaj2005.0111, 2006.

Panettieri, M., Knicker, H., Murillo, J. M., Madejón, E., and Hatcher, P. G.: Soil organic matter degradation in an agricultural chronosequence under different tillage regimes evaluated by organic matter pools, enzymatic activities and CPMAS ${ }^{13} \mathrm{C}$ NMR, Soil Biol. Biochem., 78, 170-181, doi:10.1016/j.soilbio.2014.07.021, 2014.

Plaza, C., Courtier-Murias, D., Fernández, J. M., Polo, A., and Simpson, A. J.: Physical, chemical, and biochemical mechanisms of soil organic matter stabilization under conservation tillage systems: A central role for microbes and microbial byproducts in C sequestration, Soil Biol. Biochem., 57, 124-134, doi:10.1016/j.soilbio.2012.07.026, 2013.

Preston, C. M., Trofymow, J. A., Niu, J., and Fyfe, C. A.: PMASNMR spectroscopy and chemical analysis of coarse woody debris in coastal forests of Vancouver Island, Forest Ecol. Manag., 111, 51-68, doi:10.1016/S0378-1127(98)00307-7, 1998.

Riggs, C. E. and Hobbie, S. E.: Mechanisms driving the soil organic matter decomposition response to nitrogen enrichment in grassland soils, Soil Biol. Biochem., 99, 54-65, doi:10.1016/j.soilbio.2016.04.023, 2016.

Sanaullah, M., Rumpel, C., Charrier, X., and Chabbi, A.: How does drought stress influence the decomposition of plant litter with contrasting quality in a grassland ecosystem?, Plant Soil, 352, 277-288, doi:10.1007/s11104-011-0995-4, 2012.

Shan, Y., Chen, D., Guan, X., Zheng, S., Chen, H., Wang, M., and Bai, Y.: Seasonally dependent impacts of grazing on soil nitrogen mineralization and linkages to ecosystem functioning in Inner Mongolia grassland, Soil Biol. Biochem., 43, 1943-1954, doi:10.1016/j.soilbio.2011.06.002, 2011.

Socher, S. A., Prati, D., Boch, S., Mueller, J., Klaus, V. H., Hoelzel, N., and Fischer, M.: Direct and productivity-mediated indirect effects of fertilization, mowing and grazing on grassland species richness, J. Ecol., 100, 1391-1399, doi:10.1111/j.13652745.2012.02020.x, 2012.

Spaccini, R., Piccolo, A., Conte, P., Haberhauer, G., and Gerzabek, M. H.: Increased soil organic carbon sequestration through hydrophobic protection by humic substances, Soil Biol. Biochem., 34, 1839-1851, doi:10.1016/S0038-0717(02)001979, 2002.

Steelink, C.: Implications of elemental characteriastucs of humic substances, Humic substances in soil, sediment and water, edited by: Aiken, G. R., McKnight, D. M., Warshaw, R. L., New York, John Wiley Sons, Inc., 457-476, 1985.

Steinauer, K., Tilman, D., Wragg, P. D., Cesarz, S., Cowles, J. M., Pritsch, K., and Eisenhauer, N.: Plant diversity effects on soil microbial functions and enzymes are stronger than warming in a grassland experiment, Ecology, 96, 99-112, doi:10.1890/140088.1, 2015.

Stevenson, B. A., Sarmah, A. K., Smernik, R., Hunter, D. W., and Fraser, S.: Soil carbon characterization and nutrient ratios across land uses on two contrasting soils: Their relationships to microbial biomass and function, Soil Biol. Biochem., 97, 50-62, doi:10.1016/j.soilbio.2016.02.009, 2016.
Ussiri, D. A. N. and Johnson, C. E.: Characterization of organic matter in a northern hardwood forest soil by ${ }^{13} \mathrm{C} N \mathrm{NMR}$ spectroscopy and chemical methods, Geoderma, 111, 123-149, doi:10.1016/S0016-7061(02)00257-4, 2003.

Vance, E. D., Brookes, P. C., and Jenkinson, D. C.: An extraction method for measuring soil microbial biomass C, Soil Biol. Biochem., 19, 703-707, doi:10.1016/0038-0717(87)900526, 1987.

Wang, R., Filley, T. R., Xu, Z., Wang, X., Li, M. H., Zhang, Y., Luo, W., and Jiang, Y.: Coupled response of soil carbon and nitrogen pools and enzyme activities to nitrogen and water addition in a semi-arid grassland of Inner Mongolia, Plant Soil, 381, 323-336, doi:10.1007/s11104-014-2129-2, 2014.

Wang, X.-G., Sistla, S. A., Wang, X.-B., Lü, X.-T., and Han, X.-G.: Carbon and nitrogen contents in particle-size fractions of topsoil along a $3000 \mathrm{~km}$ aridity gradient in grasslands of northern China, Biogeosciences, 13, 3635-3646, doi:10.5194/bg-13-3635-2016, 2016.

White, R., Murray, S., and Rohweder, M.: Pilot Analysis of Global Ecosystems: Grassland Ecosystems, World Resources Institute, Washington, DC, 2000.

Wu, J., Joergensen, R. G., Pommerening, B., Chaussod, R., and Brookes, P. C.: Measurement of soil microbial biomass C by fumigation extraction: an automated procedure, Soil Biol. Biochem., 22, 1167-1169, doi:10.1016/0038-0717(90)90046-3, 1990.

Zech, W., Senesi, N., Guggenberger, G., Kaiser, K., Lehmann, J., Miano, T. M., and Schroth, G.: Factors controlling humification and mineralization of soil organic matter in the tropics, Geoderma, 79, 117-161, doi:10.1016/S00167061(97)00040-2, 1997.

Zhang, Y., Yao, S., Mao, J., Olk, D. C., Cao, X., and Zhang, B.: Chemical composition of organic matter in a deep soil changed with a positive priming effect due to glucose addition as investigated by ${ }^{13}$ C-NMR spectroscopy, Soil Biol. Biochem., 85, 137 144, doi:10.1016/j.soilbio.2015.03.013, 2015.

Zhao, H., Lv, Y., Wang, X., Zhang, H., and Yang, X.: Tillage impacts on the fractions and compositions of soil organic carbon, Geoderma, 189, 397-403, doi:10.1016/j.geoderma.2012.06.001, 2012.

Zhou, Z., Cao, X., Schmidt-Rohr, K., Olk, D. C., Zhuang, S., Zhou, J., and Mao, J.: Similarities in chemical composition of soil organic matter across a millennia-old paddy soil chronosequence as revealed by advanced solid-state NMR spectroscopy, Biol. Fert. Soil, 50, 571-581, doi:10.1007/s00374-013-0875-6, 2014. 